\title{
PRESENT SITUATIONS AND ISSUES OF PLANNING AND IMPLEMENTATION REGARDING LAND-USE AND TRANSPORT IN DEVELOPING METROPOLISES
}

\author{
Kazuaki MIYAMOTO* and Rungsun UDOMSRI**
}

\begin{abstract}
The objectives of the present study are, with regards to land-use and transport including environment, to investigate present situations, to identify issues in the planning and implementation stages, and lastly, to propose subjects to be tackled in order to realize "integrated planning and implementation" of "integrated land-use and transport" in developing metropolises. Following intensive investigations for the cases of the SouthEast Asian metropolises, the interaction structure is represented as a system which contains markets and governmental agencies. Pigeonholes are then set up to identify issues from the two viewpoints of "land-use and transport" and "planning and implementation". The identified key issues are further examined from various viewpoints.

Key Words : developing countries, land-use, transport, planning and implementation
\end{abstract}

\section{INTRODUCTION}

\section{(1) Background}

In most metropolises of developing countries, aside from road traffic congestion, many kinds of urban problems which may be represented by excessive agglomeration of economic activities, environmental deterioration and worsening safety, are emerging and various discussions are being made on how they can be alleviated. Since land-use and transport are structural elements of the metropolises, most of the social and economic problems are attributed to them. Thus, land-use and transport can be regarded as both causes and effects of most of the urban problems.

In addition, there is a growing concern that the global environment is closely related to urban problems of developing metropolises, since future increase in environmental pollutants from developing countries may have a significant adverse effect on the global environment. Since environmental matters can be regarded as nothing more than outcomes of external diseconomy of land-use and transport markets, land-use as well as transport in developing countries are two of the most important and essential elements also in the discussion on the global environment.

It is well known that the interaction between land-use and transport should be taken into consideration in the planning process. However,

* Member of JSCE, Dr. Eng., Associate Professor, Department of Civil Engineering, Yokohama National University (156 Tokiwadai, Hodogaya-ku, Yokohama, 240 Japan).

** Member of JSCE, M. Eng., Graduate Student, Departmet of Civil Engineering, Yokohama National University. the problem in conventional planning regarding land-use and transport lies in the fact that each of them is actually dealt with independently of the other. This is the case, in a greater or lesser degree, for not only developing countries but also for developed countries. A new and innovative approach to integrate transport strategies for urban transport policy formulation has been proposed and is being actually employed in the U.K. ${ }^{11}$. However, it does not incorporate land-use policies explicitly in its scheme, hence it still remains mainly in the sphere of transport. Since urban changes in developing metropolises are so rapid and dramatic, it can be said that integrated planning of land-use and transport is much more important and necessary in developing metropolises than in developed metropolises.

In addition, institutions in charge of plan implementation are usually different from those dealing with planning in developing countries. Although, in most developing metropolises, there have been not a few transport plans or studies, only very limited part of them have been actually implemented. This fact suggests that there might be more underlying problems in the stage of plan implementation to say nothing of that there are some problems in the planning stage and in the plans themselves. The relation between planning and implementation is therefore also very important in this regard.

\section{( 2 ) Objectives}

The objectives of the present study are to investigate present situations of transport and landuse including environment, to identify, in both planning and plan implementation stages, the issues regarding land-use and transport including environment, and to propose subjects to be tackled 
for realizing "integrated planning and implementation" of "integrated land-use and transport" in developing metropolises. The main objective of the paper therefore is to identify the most essential and important subjects for research and practice related to urban development and transport in developing countries.

( 3 ) "Developing Metropolises" in this study

Although it is originally intended that the discussion presented in this paper is generally applicable to such developing metropolises as those located in South-East Asian countries ; Thailand, Philippines, Malaysia, Indonesia and other ASEAN countries/areas, actual cases for Bangkok are mainly used as examples to support the discussion.

However, some parts of the discussion in this paper are still valid for developing or growing metropolises even in industrialized countries and areas.

(4) Sources of Data and Information

Some parts of the investigations for this study were conducted with the assistance of the United Nations Center for Regional Development through workshop meetings which had invited representatives from several Asian metropolises. The authors should mention that some parts of the content of this paper were derived from the information and discussions in the workshop meetings ${ }^{2)}$ and the earlier version of this research was reported in an issue of the Regional Development Dialogue ${ }^{3)}$. In this paper, the conceptual framework of the issue identification has been revised and more intensive discussions based on the framework are extended. In addition, the authors made investigations through interviews with responsible officials and researchers in Bangkok to follow up the results obtained from the UNCRD meetings.

\section{PRESENT SITUATIONS, PLAN- NING AND PLAN IMPLEMENTA- TION OF TRANSPORT, LAND- USE AND ENVIRONMENT FOR THE CASE OF BANGKOK}

\section{(1) Present Situations}

Among the various cases in urban transport in developing metropolises, Bangkok is one of the best examples in the senses that it is one of the representative cases which have been suffering from many kinds of urban problems pertaining to developing metropolises and that the degree of severity of these problems is also one of the worst because of the rapid and dramatic urban development in recent years.

"LIFE IN THE SLOW LANE; Bangkok's Traffic Nightmare" was one of the cover headlines of an issue of "Newsweek" magazine". The article under the title reported the terrible situation regarding road traffic in Bangkok which contained not only traffic congestion but also environmental pollution. The case of Bangkok is one of the worst even among those of developing countries, although other developing metropolises are also facing nearly similar problems.

Recent measurements of traffic speeds ${ }^{6)}$ show peak-hour speeds of under $10 \mathrm{~km} / \mathrm{h}$ on most main roads inside the Middle Ring Road (MRR) which surrounds an urbanized area of $140 \mathrm{~km}^{2}$. With regards to public transport, Bangkok does not have any segregated mass transit system. About 7200 buses are normally available for services. This makes the share of buses and mini-buses to $76 \%$ of the total public transport. Besides buses and minibuses, taxis, a variety of mini-taxis, and boats are available in Bangkok. Motorization gradually started since the mid-1970's, and has drastically accelerated in the 1980's. The average increase rate of passenger cars in 1980's was about $11 \%$ per annum. The number of cars in the Bangkok Metropolitan Area and three other provinces in the vicinity was estimated at about 562000 in 1989 and is forecasted to increase to 2.1 to 3.7 times the current figures by the year 1997 and 2006, respectively ${ }^{5}$. According to a road network inventory which covered $1640 \mathrm{~km}^{2}$ in the central part of the Bangkok Metropolitan Region, the total road length is about $3800 \mathrm{~km}$ of which $978 \mathrm{~km}$ are the major roads ${ }^{6}$. Within the MRR area, the area of roads occupies only $10.7 \%$ of total area, and the average length per square $\mathrm{km}$ is $8.1 \mathrm{~km}$.

The present urban development is characterized by a rush in construction of office buildings, hotels and condominiums in and around the central area, and of supermarkets and department stores in the fringe areas. Contrary to the rush of urban development, large portions of land, particularly those in the suburbs, are not being used effectively. There exist a large number of scattering plots of land which are not actually used for any purpose. The pattern of uneven development is further exacerbated by low property tax and lack of effective land policies. The fragmented pattern of land ownership has made it more difficult to assemble tracts for development. In addition, land price have been soaring dramatically at a rate of about twenty percent per annum since 1988. This brings about severe difficulties in obtaining land for public works.

Monitoring data indicate that the level of lead in the air around Bangkok has increased from 0.1 to 1.0 micrograms $/ \mathrm{m}^{3}$ from 1983 to 1986 , to between 0.6 and $5.45 \mathrm{micrograms} / \mathrm{m}^{3}$ from 1987 to 1989 . 
Reported blood lead levels are at least three times of those found in the United States and Western Europe. Suspended particulate matter and other kinds of pollutants in the air shows similar tendency and also exceed the standards of the National Environmental Board. Such pollution of the air as well as noise disturbance are mainly caused by the road traffic in Bangkok. In addition, solid waste collection and disposal is another pressing problem.

\section{( 2 ) Planning and Plan Implementation}

The development of transport infrastructure in Bangkok has been following the policies and guidelines that have been set in the five-year National Economic and Social Development Plan. In addition to the plans, there were other transport plans such as the Bangkok Transportation Study which provided a comprehensive long-term transport plan, the Short Term Transport Review and the Seventh Plan Urban and Regional Transport, which proposed broadly the same approach as the former plan. There have been about ten studies related to transport of Bangkok since 1975. It can be said that there is no lack, at least in terms of number, of planning or plans intended to solve the problem.

The Sixth five-year plan $(1987 \sim 1991)^{7)}$ period is now over. Most of the planned non-road investments have not been materialized. The policy requirements in the plan have been almost wholly disregarded. Although the First Stage Expressway and other numerous big roads were built, little has been done to implement other vital elements of the plan. As for the the Second Stage Expressway, it has brought about serious conflicts in the procedures of Build-Operate-Transfer scheme in spite of that it is now in operation. Many other proposed roads have not been commenced. Although the contract of a mass rail-transit project had been once signed with private sector at long last after about six years' negotiation, the contract was cancelled and the project is still uncertain. In addition, nothing has been done to introduce busways, nor to restraint traffic and little has been done to rectify the lack of distributor roads, nor to reform the bus industry and raise the quality of bus service.

Several land-use plans for Bangkok have been made and revised many times since 1960 . However, only a very small part of the plan has been implemented because of lack of legislative support. The most recent plan has been authorized but the effectiveness is still uncertain because of the lack of legal mandate. The procedure for approval of these plans are complex and time-consuming. Therefore, the Bangkok Metropolitan Administration has to employ the Building Control Act of 1979 as an indirect tool to control the development of landuse. The measures used in land-use control are mainly zoning control which are in terms of height, type, and use control of building. However, these measures are limited only for some specific type of land-use and areas which has resulted in a mixed land-use and haphazard growth in some areas of Bangkok.

The Office of the National Environment Board is responsible for controlling, preventing, and mitigating the pollution problem by coordinating with the concerned agencies. However, the implementation of environmental policies requires strong support and cooperative work among many concerned agencies.

\section{(3) Institutions}

The institutional problem involved in both landuse and transport sector is that there are various organizations related to them. For example, about 37 agencies and four statutory committees are involved in various aspects of planning, evaluation, approval, implementation, maintenance or control of urban transport in Bangkok ${ }^{6}$. The complex interrelationships among agencies result in overlapping responsibilities as well as in less interaction among them. The institutional deficiencies have been identified as a main reason for the failure of the implementation of land-use and transport plan in Bangkok ${ }^{5)}$. However, certain institutional changes to improve the planning and coordination in the transport sector are in active consideration. Efforts are made to strengthen the Office of the Committee for the Management of Road Traffic which plays a key role in planning and management of road transport, to elevate it to a higher status, and to provide it with more authority than the other institutions.

\section{OVERVIEW OF THE SYSTEM OF TRANSPORT, LAND-USE AND EN- VIRONMENT IN THE DEVELOP- ING METROPOLIS}

(1) Elements of the System in the Study

In this study, the system related to land-use, transport and environment in the metropolis, either developing or developed, is grasped as shown in Fig.1. In this figure, transport as well as land-use are composed of two elements; markets and governmental agencies. They may correspond with the idea of civil sphere and civic spheres in landuse, transport and environment shown by Black 8 . It is assumed that the environment is an externality of both land-use and transport and that it does not constitute a market by itself. Environment can be regarded as nothing but a situation of environmen- 


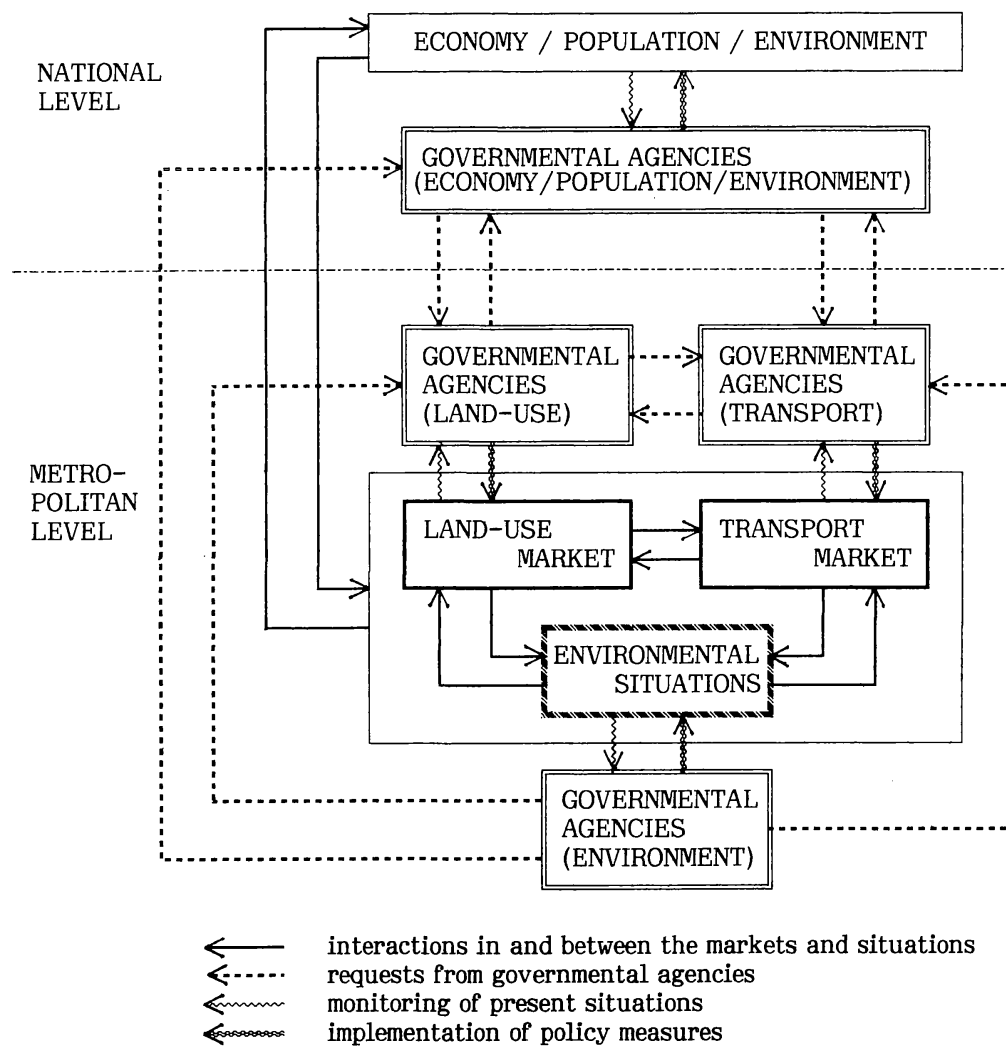

Fig.1 Configuration of the System of Governmental Agencies, Land-Use and Transport Markets, and Environmental Situations in the Metropolis

tal qualities most of which land-use and transport determine. Therefore, the treatment of environment in the system is different from those of transport and land-use. However, in a wider sense, it can be said that land-use, transport and environment constitute a market in spite of that there are a variety of externalities in it. As for macroscopic economy of the metropolis, it is closely related to the national economy itself, because most economic activities of the country are usually concentrated in a metropolitan area in developing countries. It is also composed of market and governmental agencies, the former of which covers transport and land-use as well as environment in the microscopic level. In Fig.1, all agencies related to land-use, transport and environment of the central government are represented by governmental agencies (economy/population/environment). The metropolitan economy has interactions with national and internationally regional economies and as far as global economies. Particularly for the case of the environment, pollutants as well as land cover changes in the microscopic level, such as emissions from vehicles and deforestation, affects the global environment.

\section{(2) Interaction between Markets, Situa-} tions and Governmental Agencies

Markets and governmental agencies of land-use and transport mutually interact with each other as follows. In each market, the situation is determined by the market conditions as well as conditions given by the related markets. The governmental agencies in charge of the market is monitoring the situation through surveys and studies. Based on the studies, they make a plan and select policy measures for the implementation of the plan. The policy measures are given to the market and the condition which have relevant influences through interactions between markets are also changed. In the process of planning and implementation, each governmental agency interacts with each other, whether it is well coordinated or not. It is usual that agencies in charge of the environment have only functions of planning and have little responsibility in the implementation. Policy measures regarding environment are usually implemented by other implementing agencies which deal with land-use, transport and/or economy.

\section{( 3 ) Interaction between Agencies}

If the interactions between agencies are well 
Table 1 Pigeonoholes for Issue Identification concerned with Land-Use, Transport and Environment

\begin{tabular}{cccc}
\hline & Planning(P) & $\stackrel{\leftarrow}{ }$ & Implementation(I) \\
\hline Land-Use $(\mathrm{L})(\rightleftharpoons$ Environment $)$ & {$[\mathrm{L} / \mathrm{P}]$} & {$[\mathrm{L} / \mathrm{P} \rightleftharpoons \mathrm{I}]$} & {$[\mathrm{L} / \mathrm{I}]$} \\
$\downarrow \uparrow$ & {$[\mathrm{L} \rightleftharpoons \mathrm{T} / \mathrm{P}]$} & {$[\mathrm{L} \rightleftharpoons \mathrm{T} / \mathrm{P} \rightleftharpoons \mathrm{I}]$} & {$[\mathrm{L} \rightleftharpoons \mathrm{T} / \mathrm{I}]$} \\
Transport(T) $(\rightleftharpoons$ Environment $)$ & {$[\mathrm{T} / \mathrm{P}]$} & {$[\mathrm{T} / \mathrm{P} \rightleftharpoons \mathrm{I}]$} & {$[\mathrm{T} / \mathrm{I}]$}
\end{tabular}

L: Land-Use ; T: Transport ; $\rightleftharpoons$ : Interaction ;

e.g. $[\mathrm{L} / \mathrm{P} \rightleftharpoons \mathrm{I}]$ :interaction between planning and implementation in land-use

coordinated, the separated agencies would be able to work efficiently as if they constituted a single planning and implementing organization. But this is not the case in most developing metropolises. In addition, it is very rare the case to find agencies which are concerned with the same market, landuse or transport, that are well coordinated, to say nothing of the coordination between land-use and transport agencies.

\section{ISSUES RELATED TO TRANS- PORT AND LAND-USE IN DE- VELOPING METROPOLISES}

\section{(1) Setting of Pigeonholes and Identifica- tion of Issues}

There are various issues related to land-use and transport in developing metropolises as described before. In this study, they are reviewed from the viewpoints of "land-use and transport" and "planning and implementation" as shown in Table 1.

The interaction between land-use and transport should be taken into consideration not only in the planning stage but also in the implementation stage. In addition, since the linkage between planning and implementation should also be wellcoordinated, another viewpoint of the relation between planning and implementation is needed to review the issues. Since environment is regarded as an externality of both land-use and transport as described previously, it is represented as an attachment to land-use and transport in this study as shown in Table 1. On the other hand, there are some levels of time leads and lags in the interactions between the two viewpoints. Various interactions between land-use and transport as well as planning and implementation all take place over vastly different time scales. Key issues concerning land-use and transport of developing metropolises have been listed up in Table 2 by following the pigeonholes shown in Table 1.

The listing up of the key issues was made originally in the discussions at the said workshop meetings. From the original table of key issues, we selected issues mainly related to one of the "developing metropolises" of this study. They are not always common issues for subject metropolises. Although some of specific issues will be referred to each metropolis as examples in the following sections, other metropolises are facing most of the issues in less degree. Issues without referring to metropolises' name are regarded common among them. In addition, as mentioned in the first chapter, it is natural that some of them are also common with metropolises in developed countries.

\section{(2) Issues related to Land-Use Planning}

In most developing metropolises, it is very difficult to set up the future scope of the city development since present changes are so rapid and dramatic, and moreover not stable. In addition, there are very few effective policy measures to take. Hence, land-use plans prepared by the governments are mostly nothing but nominal future plans without being accompanied by effective control/guidance measures. As for planning techniques, which are usually immature, scientific approaches such as quantitative models are scarcely used, and available data for necessary analysis are mostly very limited and not so reliable. Largescale land owners, who generally have strong political influence, are intervening in the land-use planning when it involves their own lands. The relationship between land-use development and transport is also not well understood.

\section{( 3 ) Issues related to Implementation of Land-Use Plan}

The non-existence of effective regulatory measures on land-use and development has rendered it impossible to implement a land-use plan. Since in many metropolises the sites and the total floor areas are not subject to control by the government, the impact of the development is difficult to assess and the corresponding transport infrastructure cannot be planned. Land acquisition problem is one of the most deterministic problems in infras- 
Table 2 Key Issues Related to Land-Use / Transport and Environment Planning and Implementation in Developing Metropolises

\section{[Land-Use/Planning]}

(1) Missing planning goals and objectives [1,5]

(2) Missing quantitative analysis models [3]

(3) Lack of effective policy measures [1]

(4) Insufficient understanding of present situations [2]

(5) Uncertainty of the future framework [3]

(6) Immature planning technique [3,7]

(7) Socio-political pressures from land owners [4]

(8) Insufficient understanding of the relationship between land-use and environment $[3,7]$

(9) Lack of idea on the utilization of land-use plan as a mean for environmental control $[1,5]$

[Land-Use/Implementation]

(1) Lack of effective land-use regulation/guidance measures [1]

(2) Lack of effective taxation system [1]

(3) Unstable financial basis [6]

(4) Fragmented land ownership [4]

(5) Lack of power to control developments by the private sector $[1,5]$

(6) Physical, historical and social constraints in urban development $[1,4,5]$

(7) Complex and time-consuming procedures for permission and authorization [5]

(8) Lack of effective power to acquire lands for public works $[1,4]$

(9) Lack of " guidelines for environmental consideration during implementation [7]

\section{[Transport/Planning]}

(1) No firm or conflicting transport policies [5,7]

(2) Lack of coordination between organizations [5]

(3) Inappropriate analysis models [3]

(4) Insufficient understanding of present situations [2]

(5) Uncertainty of the future framework [3]

(6) Immature planning technique $[3,7]$

(7) Contradiction with the economic policy [1]

(8) Limited options on transport infrastructure developments $[1,6]$

(9) Lack of idea on transport coordination $[1,5,7]$

(10) Inconsistent planning techniques $[3,7]$

(11) Socio-political influence $[4,5]$

(12) Lack of idea on controlling the environment through transport policies [7]

\section{[Transport/Implementation]}

(1) Financial constraints for investments [6]

(2) Lack of determination/political will to implement [7]

(3) Overlapping functions of agencies [5]

(4) Inadequate manpower and logistical support $[6,7]$

(5) Resistance from land owners/residents [4]

(6) Conflicts with other projects $[1,5]$

(7) Lack of common purpose/uncooperative work [5,7]

(8) Complex and time-consuming procedures for permission and authorization [5]

(9) Strong opposition from the economic sector to demand control policies $[1,5]$

\section{[Land-Use/Planning $\rightleftharpoons$ Implementation]}

(1) Lack of legal mandate to implement [1]

(2) Lack of prompt monitoring and reviewing [2,3]

(3) Lack of coordination between planning and implementing organizations [5]

(4) Complex procedures to authorize plans for implementation [5]

[Transport/Planning $\rightleftharpoons$ Implementation]

(1) Lack of legal mandate to implement [1]

(2) Lack of prompt monitoring and reviewing [2]

(3) Lack of coordination between planning and implementing organizations [5]

(4) Complex procedures to authorize plans for implementation [5]

[Land-Use $\rightleftharpoons$ Transport/Planning]

(1) Lack of appropriate planning models [3]

(2) Lack of planning support system [3]

(3) Lack of coordination among organizations [5]

(4) Lack of idea on the utilization of land-use policies for transport [1]

(5) Lack of idea on the utilization of transport policies for land-use [1]

[Land-Use $\rightleftharpoons$ Transport/Implementation]

(1) Delay in infrastructure construction $[5,6]$

(2) Inconsistent development of projects [5]

(3) Lack of coordination between organizations [5]

[Land-Use $\rightleftharpoons$ Transport/Planning $\rightleftharpoons$ Implementation]

(1) Missing link between land-use change and transport planning $[1,2,3,5]$

(2) Missing link between transport change and land-use planning $[1,2,3,5]$

(3) Lack of coordination between organizations [5]

main causes underlying the issue: [1] policy measures, [2] survey, [3] analysis tools, [4] socio-economic systems of land, [5] institutional set-up, [6] financing, and [7] education 
tructure development in most metropolises. Fragmentation of land ownership has also made it more difficult, particularly in Jakarta and in Hong Kong. More specifically, the relocation of squatters is also a political issue in cities like Manila, Jakarta and Bangkok. In some instances, multiple titling and unknown ownership have delayed land acquisition for development projects such as in Jakarta. In Jakarta, there is no control on the actual use of the land because the land-use development plans prepared by the governments have no legislative power.

( 4 ) Issues related to Transport Planning

In some developing metropolises, firm and consistent transport policy is lacking : the policy for restricting the growth of private cars does not exist in Manila although the use of mass transit and pubic transport is encouraged; and in Kuala Lumpur, people are encouraged to buy cars as the cars are made more affordable or are manufactured locally. There are very few comprehensive transport policies in developing metropolises. As for planning techniques, conventional transport planning models with slight modifications are usually used regardless of the characteristics of each developing metropolis. In addition, data survey uses conventional methods which require much man-power for collection and long time for processing. Difficulty in land acquisition and low feasibility of large-scale transport investments also reduce options of policy measures in the stage of planning.

\section{( 5 ) Issues related to Implementation of Transport Plan}

There are a number of problems with the implementation of transport infrastructure investments. Financial constraint is one major difficulty in providing roads and mass rapid transit systems, as in Manila and Bangkok. For the latter, the acquisition of land for transport project construction is also difficult due to inadequate legislative and institutional arrangements. Lack of determination of the concerned authorities to proceed with planned implementation in Bangkok has sometimes prevented the making of the right decision on time. Enforcement is another problem in many cities where it is characterized by the existence of a multitude of enforcement agencies and their overlapping functions. This fact is further compounded by inadequate manpower and logistical support. For example, bus lanes in Bangkok are being taken up by private vehicles and no effective actions are being taken to solve this particular problem. Another difficult problem is the increasing political influence over government's decision, as is the case in Bangkok and in Hong Kong.

\section{(6) Issues related to Integrated Planning of} Land-Use and Transport

Apparently, there is a lack of integrated planning in land-use and transport developments in many Asian metropolises. This leads to uncoordinated and consequently inefficient urban functioning and growth which cause serious traffic congestion as often seen in developing countries. This is due to the fact that there is no effective methodology nor is there any substantial mechanism to integrate/ coordinate the land-use and transport planning process. The absence of a central unit or coordinating organization among departments is the major factor for the lack of integrated land-use and transport planning. The complicated structure of the current institutional set-up in most cities has made it difficult to define a clear line of responsibility among the relevant agencies for land-use and transport planning. In most cases, ad hoc coordinating committees fail to reach agreements or even fail to adopt agreements and decisions. Coordination mechanisms are temporary in nature and the persons involved are changed frequently. As for planning techniques, few analysis models which can deal with the interaction between land-use and transport are used.

(7) Issues related to Interaction between Planning and Implementation

Serious problems also arise from the lack of interaction between the planning process and the implementation process both for land-use and transport developments. Problems will arise, for example, when all of the recommended projects cannot be implemented in accordance with the desired schedule. This, in turn, will affect the planning process and its outputs which may have to be reviewed and revised.

\section{EXAMINATION OF ISSUES AND IDENTIFICATION OF SUBJECTS TO BE TACKLED}

\section{(1) Classification of Causes underlying the Raised Issues}

The issues listed up in the previous chapter are examined from other viewpoints to identify subjects which should be tackled for realizing the integrated planning and implementation for landuse and transport. The viewpoints are set up by classifying the causes which are underlying the raised issues. They are policy measures, survey, analysis tools, socio-economic systems of land, institutional set-up, financing, and education. These cover most of the main causes underlying the said issues as shown in Table 2.

\section{( 2 ) Policy Measures}

Based on the above-mentioned evidences, one of 
Table 3 Examples of Implementation Measure Elements of Land-Use, Transport and Environmental Policies in Developing metropolises
[Regulation]
(1) Bus priority/exclusive lanes
(2) Unleaded gasoline
(3) Land-use zoning
(4) Building control

\section{[Taxation/Pricing]}

(1) Vehicle import/purchase taxes

(2) Fuel taxes

(3) Land-use taxes

(4) Development charges

\section{[Investment]}

(1) Provision of road network
(2) Provision of Mass Rapid Transit
(3) Land development/readjustment
(4) Housing development

[Operation]

(1) Mass transit operation

(2) Area traffic control

(3) Flexible working hours

(4) Open hours of shops

\section{[Education]}

(1) Car pooling

(2) Ride sharing

(3) Promotion by mass media the most important issues is how to adopt appropriate measures or instruments that would facilitate the implementation of plans. Only with appropriate implementation measures, can the plan be translated into reality. For this purpose, it is the first necessary to formulate a comprehensive checklist of both land-use and transport policy measures for possible adoption by practitioners. This would serve as a directory of prescriptive instruments to address the various land-use and transport problems faced within individual metropolises. Usually, each of them is regarded as a measure specific to one of land-use and transport. But usually it can also be a measure, sometimes a very strong one, for the rest through the interactions. In addition, an actual set of policy measures in integrated planning would be a combination of these policy measure elements. The concept of the integrated policy measures of this study is same as that of the integrated strategies approach ${ }^{1)}$ and/or management approach in transport planning except that the approach of this study covers as far as landuse and environment explicitly. Selection of policy measure elements should be made by taking into consideration the interaction. Some examples of policy measure elements are listed in Table 3.

The following criteria could be used for evaluation of each measure element ; (1) the nature of the measure : regulation, pricing/taxation, investment, operation or education, (2) the direct and indirect scope of its influence : land-use (type of land-use), transport (mode), environment (kind) or others, (3) the effects : promotion or restriction / supply or demand, (4) the location (site) : site-specific, linear, area-wide, city or regional wide, or non location-specific, (5) the length of time it is likely to take to implement, (6) the length of time it is likely to actualize the effect, (7) the cost that is likely to be incurred, (8) the administrative manpower capacity that likely to be incurred.

\section{(3) Survey}

The first step of the planning process is to understand the present situation of the metropolis and to identify the issues to be tackled. For this purpose, it is necessary to analyse the present situation based on land-use and transport data as well as other related data. But, in reality, the availability of the data is usually very low in most developing countries. Therefore, for better planning, one should start building the system by acquiring the necessary data for land-use and transport planning. This means a periodical data survey system has to be set up first. Moreover, a new method should be developed for the survey in developing countries. Since developing metropolises are dynamically changing, conventional methods which take much personnel and long time for data acquisition and processing are not always appropriate approaches for developing countries.

In addition, there exists another problem that such limited data are not always effectively used among related agencies. It is also very important to establish system in which available data can be in common and used effectively among concerned agencies.

\section{(4) Analysis Tools}

It is well known that the interaction between land-use and transport should be taken into consideration in the planning process. Integrated land-use and transport models which deal with both land-use and transport as well as the interaction between them have been developed as described in Webster, et al.9). However, there have not been many cases which employed such integrated land- 
use and transport models in actual planning even in developed countries. An integrated model should be built in accordance with the objectives of its application. The model should ideally represent the universe of land-use and transport as briefly as possible, so far as it satisfies the requirements given by the objectives. Bigger models are not necessarily better models. Provision of an analysis model with understandable presentation tool using computer graphics will promote coordination among governmental agencies in the stages of both planning and implementation. With the analysis tool, they can discuss on the integrated land-use and transport and compare possible options of policy measures with each other. It can be expected that this kind of technical development is to bring about a better institutional set-up. In addition, a user-friendly analysis system can make it possible for both planners and implementers to analyze long-range or action plans flexibly even in uncertain future framework of the developing metropolis.

Since it takes long time and big cost to build an analysis system which covers land-use, transport and environment, it is not feasible for each local government of developing metropolises to originally develop it by itself. Therefore, it is worth while for researchers to establish an methodology to provide developing metropolises with a standard system which has enough flexibility to install existing stocks and future developments of landuse, transport and environment models as well as computer system functions ${ }^{10)}$.

\section{( 5 ) Socio-Economic Systems of Land}

Infrastructure projects including land-use and transport developments require, in the first place, land on which facilities are to be built. But land acquisition for public works is one of the determinants of the feasibility of the project implementation. Land/space availability determines the feasibility of the projects. Each country has its particular socio-economic system of land. In addition, some countries have their own way of land acquisition. The land system intimately depends on the social custom and religious backgrounds of the country. In developing countries, there are a variety of rights related to land; for land owners and leasers, and sometimes even for squatters. It is very important to study the land system of each country since it is expected that the comparison between them gives a country some useful suggestions.

\section{( 6 ) Institutional Set-Up}

Institutional problems among organizations concerning land-use and transport is one of the most difficult problems to be solved in realizing integrated land-use and transport planning and implementation. Without good coordination between organizations, integrated planning and implementation cannot be conducted. With the various forms of institutional organizations, it is difficult to develop and/or recommend a single model that is applicable for all the metropolises concerned, considering the variety and disparity in the practice of democratic principles. Also there still exist wide variations in social, political and physical considerations. The example of one metropolis might give good suggestions to another metropolis.

It is necessary to provide the concerned organizations with a forum in which they can discuss on various policies as well as their implementing measures. Such analysis tools as described in the previous part are expected to work for this purpose. Without such a concrete and understandable system it is nearly impossible for the organizations to attain mutual consensus to take an integrated strategy. But it is nothing but one of the requirements to realize a better institutional set-up.

(7) Financing

The mechanisms to get the cooperation of the private sector to cover shortage of public funds should be studied. For example, concession projects such as Build-Operation-Transfer should be investigated and new methods may be developed. But it should be noted that to hand over profitable projects to the private sector means to lose a "cash box" and to give up a bigger project development through internal cross-subsidization. In addition, for developing countries, Official Development Assistance from other developed countries and funds from international lending institutions are also available. This means that there are more options in financing the public works for developing countries than for developed countries. In addition, studies on the methodology to identify the beneficiaries, in particular by the construction of mass rail transit, should be made with a view to the impacts to urban development and environment. The project might be able to finance part of the cost by the value capture. But the feasibility of applying the value capture concept to actual projects depends fully on the socioeconomic system of land of the country.

\section{( 8 ) Education}

Lack of technical experts in planning and implementation is also one of the most serious problems in developing metropolises. Provision of courses for public administration is necessary to educate public officials who are in charge of either planning or implementation of land-use and transport. Curriculum of public administration 
courses, which include infrastructure planning aiming at developing countries, should be originally developed.

In addition, advertisement or education to make the public understand the importance of proposed policies and change selfish consciousness into that which gives more priority to the public welfare. Movements for environmental consideration in most developed countries have shown the substantial impacts of these kind of advertisement.

Education cannot be expected to become a very effective policy instrument by itself, but it can become a good lubricant for the implementation of other policy measures.

\section{CONCLUDING REMARKS}

The developing metropolises are the very areas which really require integrated land-use/transport planning and implementation. To realize the integrated system, there are many problems to be solved as described in this paper. Since there are many specific characteristics in land-use and transport systems of developing countries when compared with those of developed countries, the conventional approaches developed and applied in developed countries are seldom readily applicable to developing countries. In addition, it is found that there is a tight relationship between development of an analysis tool and institutional set-up in the sense that the latter cannot be really functional without the former. In this paper, it was intended to propose subjects on which methodology as well as institutional set-up are originally developed for developing countries.

\section{ACKNOWLEDGEMENTS}

The authors would like to express their sincere appreciation to Dr. F. Vernon Webster, Mr. J. Stuart Yerrel and Prof. Michael Wegener for their kind and instructive comments on the former version of this work. They also express their appreciation to the transport and land-use experts in Bangkok, who kindly provided detailed information and gave valuable opinions, and to the participants at the two-time UNCRD international workshop meetings for providing them with useful materials and having substantial discussions. In addition, they are also very grateful to the referees for helpful comments on the earlier version of this paper. But it should be noted that the opinions expressed in this paper are solely those of the authors themselves.

\section{REFERENCES}

1) May, A.D. : Integrated Transport Strategies : a New Approach to Urban Transport Policy Formulation in the U.K., Transport Reviews, Vol 11, No. 3, pp 223 241, 1991.

2) Miyamoto, K. and Black, J.A. : Editorial Introduction, Regional Development Dialogue, Vol.13, No.3, pp.1 4, United Nations Center for Regional Development, 1992.

3) Miyamoto, K. : Integrated Land-Use Transportation Planning and Implementation for developing Metropolises, Regional Development Dialogue, Vol.13, No.3, pp.26 42, United Nations Center for Regional Development, 1992.

4) Moreau, R. : Life in the Slow Lane, Newsweek, issue of September 30, pp.16 17, 1991

5) Halcrow Eox and Associates with Pak-Poy \& Kneebone Pty Ltd. and Asian Engineering Consultants Corp., Ltd. : Seventh Plan Urban and Regional Transport (SPURT), Bangkok, 1991.

6) Japan International Cooperation Agency : The Study on Medium to Long Term Improvement/ Management Plan of Road and Road Transport in Bangkok in the Kingdom of Thailand (SIMR), Bangkok, 1990.

7) NESDB/IBRD/USAID/ADAB : Bangkok Metropolitan Regional Development Proposal, Recommended development Strategies and Investment Programs for the Sixth Plan (1987 1991), National Economic and Social Development Board, Bangkok, 1986.

8) Black, J.A. : Policy Measures for Land-Use and Transport Demand Management and Their Implications in Managing Rapidly Growing Asian Metropolises, Regional Development Dialogue, Vol.13, No.3, pp.3 25, United Nations Center for Regional Development, 1992.

9) Webster, F.V, Bly, P.H. and Paulley, N.J. : Urban Landuse and Transport Interaction - Report of the International Study Group on Land-use/ Transport Interaction (ISGLUTI), Avebury, 1988.

10) Miyamoto, K. and Udomsri, R. : Basic Concepts of an Analysis System for Integrated Policy measures of Land Use, Transport and Environment in a Metropolis, Proceedings of Infrastructure Planning, No.16(1), pp.481 $\sim 486,1993$.

(Received February 8, 1993) 
発展途上国の土地利用と交通にかかわる計画およびその実施 に関する現状と課題

宮本和明・ランサン ウドムスリ

本研究の目的は, 発展途上国における首都を含む大都市圏を主な対象に, 土地利用, 交通そして環境にかかわる課題を新しい視点から整理し，さらに，それに基づいて，今 後の研究課題を明らかにすることである。 まず, バンコクを例にその現状を再整理し， さらに，その計画および実施段階における問題を明らかにしている．そして，他の東南 アジア諸国の現状をも踏まえ,「土地利用と交通」,「計画と実施」のそれぞれの相互作 用に着目した視点を提示し，それに基づいて課題を明確にしている.さらに，これらの 課題を，政策手段，調査，分析モデル，土地制度，組織，財源，教育に着目し，今後の 発展途上国関連の研究課題について提示している. 